FIÁTH Attila - NAGY Balázs - TÓTH Péter -

- DÓCZI Szilvia - DINYA Mariann

\title{
EGYSÉGES KOCKÁZATKEZELÉSI
} MÓDSZERTAN KIALAKÍTÁSA

\section{A VILLAMOSENERGIA-IPARI ÁTVITELI RENDSZERIRÁNYÍTÓ TÁRSASÁGNÁL}

A felelốs vállalatirányítás egyik stratégiai jelentốségú tényezôje a vállalati szintű kockázatkezelés, mely napjaink egyik legnagyobb kihívást jelentố területe a vállalatvezetés számára. A hatékony vállalati kockázatkezelés nem valósulhat meg kizárólag az általános, nemzetközi és hazai szakirodalomban megfogalmazott kockázatkezelési alapelvek követése mentén, a kockázatkezelési rendszer kialakítása során figyelembe kell venni mind az iparági, mind az adott vállalatra jellemzố sajátosságokat. Mindez különösen fontos egy olyan speciális tevékenységet folytató vállalatnál, mint a villamosenergia-ipari átviteli rendszerirányító társaság (transmission system operator, TSO). A cikkben a magyar villamosenergia-ipari átviteli rendszerirányító társasággal együttmúködésben készített kutatás keretében elôálló olyan komplex elméleti és gyakorlati keretrendszert mutatnak be a szerzók, mely alapján az átviteli rendszerirányító társaság számára kialakítottak egy új, területenként egységes kockázatkezelési módszertant (fókuszban a kockázatok azonosításának és számszerúsítésének módszertani lépéseivel), mely alkalmas a vállalati szintú kockázati kitettség meghatározására.

Kulcsszavak: villamosenergia-ipar, kockázatkezelés, Monte-Carlo szimuláció

A vállalatok stratégiai irányításának egyik kulcsfontosságú folyamata a kockázatkezelés, melynek célja a vállalat üzleti tevékenységéhez kapcsolódó kockázatok minél pontosabb azonosítása és meghatározása, valamint a kockázatok számszerúsítésének és kezelhetőségének elősegítése. A vállalati kockázatkezelés definíciója , a kockázatok tudatos ismeretére és aktív kontrolljára vonatkozó szisztematikus megközelités annak érdekében, hogy a vállalat müködése egyrészt az üzleti célok, másrészt a tulajdonosok és érintettek elvárásainak megfelelöen, zavartalanul történjen." Mindezek eredményeként a hatékony kockázatkezelés képes azt biztosítani, hogy a kockázatok vállalása az üzleti sikerek érdekében meghozott felelős vezetöi döntés legyen.

\section{A kockázatkezelés jelentôsége és folyamata}

A kockázatkezelés több, egymástól jól elkülönített, de folyamatba szervezett lépésből áll, mely lépéseket az adott vállalat iparági környezetére, valamint belső müködési jellemzőire adaptáltan kell kialakítani és megvalósítani. A vállalati kockázatkezelés folyamata általánosságban az 1. ábrán (következő oldalon) látható lépésekre bontható: ${ }^{2}$

A nemzetközi és hazai gyakorlatban a vállalati kockázatkezelés folyamatára számos módszertant dolgoztak ki, melyek iparágtól független, általános eljárásokat tartalmaznak. A vállalati gyakorlatban azonban a kockázatkezelési folyamat kialakítását számos tényezô és szempont befolyásolja, ugyanis hatékony vállalati kockázatkezelés csak akkor valósítható meg, ha a 


\section{A kockázatkezelés általános folyamata}

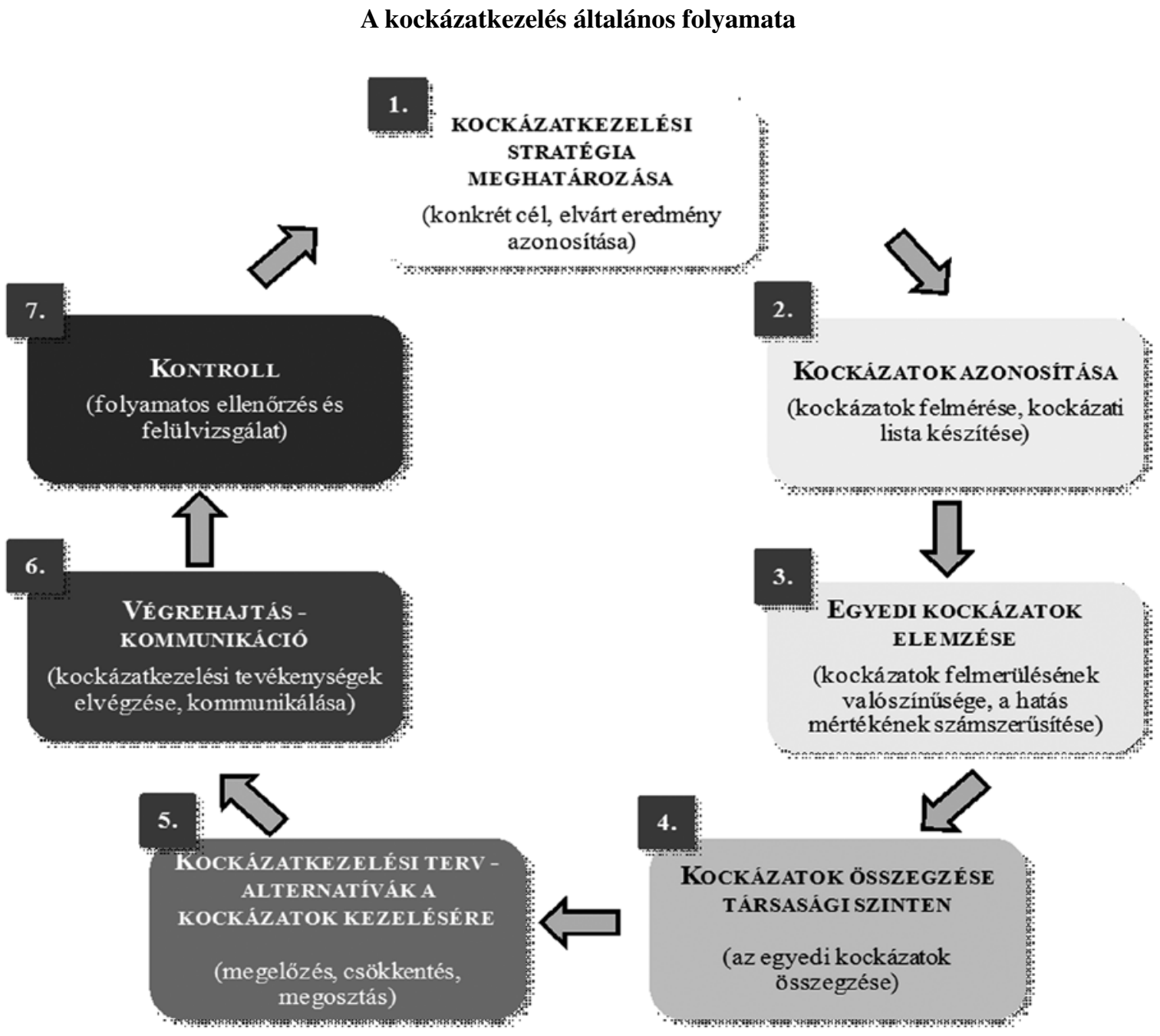

kockázatkezelési folyamatot a vállalat múködési sajátosságainak megfelelően, testre szabottan alakítják ki. Ehhez alapvető fontosságú, hogy egyaránt azonosítsák az iparági sajátosságokat, melyben az adott vállalat múködik, valamint a vállalat piacon betöltött szerepéból és múködéséból fakadó jellemzóket.

\section{Kockázatkezelés a villamosenergia-piaci és az átviteli rendszerirányító szerepéból fakadó sajátosságok tükrében}

A villamosenergia-piac szereplői számos iparág-specifikus kockázattal szembesülnek. Annak érdekében, hogy egy átviteli rendszerirányítóra szabott kockázatkezelési rendszert lehessen kidolgozni, e bizonytalanságok számbavétele szükséges, ezért elsóként az általános iparági bizonytalansági tényezóket mutatjuk be. A villamosenergia-piac szereplői számára az iparági sajátosságokból fakadó fóbb kockázati tényezốk az alábbiak: ${ }^{3}$
- energiahordozók árai: a fő energiahordozók piaci ára nagymértékben meghatározza a villamos energia ellátási láncának összes költségét. A főbb energiahordozók közül a szén, az olaj és a földgáz ára jelentős ingadozásokat mutat, mely az ellátási láncban szereplők jelentős részének kockázatokat jelent.

- termékárak: a villamos energia mint termék ára a dereguláció térnyerése óta jelentős ingadozásokat produkál, ami komoly kockázatot jelent az iparág legtöbb szereplője számára. A villamos energia tôzsdei ára jelentôsen ingadozik, mely részben a villamos energia azon sajátosságából fakad, hogy nem tárolható. Emiatt - fóleg esetleges erômúkiesés esetén - keresleti és kínálati sokkok jöhetnek létre, amelyek nagymértékú áringadozásokat okoznak a villamosenergia-tőzsdéken.

- technológia: a tudomány gyors fejlődése következtében bármikor megjelenhetnek olyan technológiák (pl. üzemanyagcellák, decentralizált áram- 
termelés), amelyek az iparág egészének vagy egyes szereplóinek szerepét csökkenthetik.

- szabályozási és politikai környezet: a villamosenergia-piacok szereplói által legnehezebben kezelhető kockázat, mely kiszámíthatatlansága miatt rövid és hosszú távon is állandó kockázatot jelent a vállalatok számára (pl. hatóság által szabályozott árak). A szabályozás számos esetben épít be olyan célokat a vállalatok múködésébe, melyek egyébként nem jelentkeznének (pl. megújuló energiák támogatása).

- kereslet volatilitása: a villamos energia iránti kereslet az elmúlt időszakban nagymértékú ingadozást mutatott, mely nagymértékú kockázatot jelent az iparág valamennyi szereplője számára.

Ezek azok az alapvetó bizonytalansági tényezók, melyek az iparág szereplói számára a legkockázatosabbak. Az átviteli rendszerirányítónak azonban a villamosenergia-piacon megkülönböztetett szerepe van, ebból fakadóan megfigyelhetốk olyan kockázatok is, melyekkel az átviteli rendszerirányító másképpen szembesül, mint a villamosenergia-piac többi szereplóje.

Elsóként az átviteli rendszerirányító feladatait és az azokból fakadó speciális kockázatokat célszerú áttekinteni. Az átviteli rendszerirányító feladatai négy nagyobb csoportba sorolhatók: ${ }^{4}$

- rendszerirányítás: forrástervezés, hálózatfejlesztési stratégia és terv elkészítése, javaslat az erômúpark fejlesztésére,

- átviteli tevékenység: átviteli hálózat tulajdonlása, tervezése, fejlesztése, karbantartása, múködtetése,

- piacmúködtetés és gazdasági tevékenység: liberalizált villamosenergia-piac múködési feltételeinek, rendszerszintú szolgáltatások piacának és a mérlegkörök rendszerének biztosítása, határkeresztezô kapacitások elosztása, kötelező átvétel (KÁT) mérlegkör múködtetése,

- nemzetközi együttmúködés: a rendszerirányítói nemzetközi szervezetekben a magyar álláspont képviselete, az együttmúködés folyamatos koordinációja, múszaki és diplomáciai tevékenység végzése a magyar érdekek érvényesítésére.

A fentiekben felsorolt feladatokból következik, hogy az átviteli rendszerirányító a villamosenergiapiac speciális szereplóje, mely többek között a teljes magyar villamosenergia-rendszer egyensúlyának fenntartásáért felelôs, ezért az átviteli rendszerirányító megfelelő múködése kulcsfontosságú az egész iparág, és így a nemzetgazdaság szempontjából is. Az átviteli rendszerirányító kockázatkezelési stratégiájának ehhez kell igazodnia: kiemelt figyelmet kell szentelnie a villamosenergia-rendszer biztonságos múködését veszélyeztetô kockázatok kezelésére. Emellett számos egyéb elvárásnak is meg kell felelni az átviteli rendszerirányító kockázatkezelési rendszerének kialakítása során: figyelembe kell venni a tulajdonos, a szabályozó hatóság, valamint a többi villamosenergia-piaci szereplő és az egyéb érintettek elvárásait is.

$\mathrm{Az}$ átviteli rendszerirányító feladatai mellett azon piacokat is célszerú megvizsgálni, melyeken a vállalat múködik. Ezek a piacok alapvetốen két csoportba oszthatók.

Azok a piacok, melyeken a TSO szolgáltatásokat nyújt a TSO monopóliumával jellemezhetók. Az átviteli hálózat használatának, a rendszerirányításnak és a rendszerszintú szolgáltatásoknak hatóság által szabályozott díjai vannak. A TSO bevétele ebben a tekintetben szabályozási és politikai döntésektôl függ, melyekre való befolyása korlátozott az átviteli rendszerirányítónak, ezáltal jelentős kockázattal szembesül a vállalat ezen a területen. A fentiek mellett csak az átviteli rendszerirányítónál lehet határkeresztezó kapacitásra jogot szerezni. Ebben az esetben a TSO bevétele a kereslet és a kínálat nagyságától függ (a jellemzóen aukciókon keresztuil történô értékesítés árai nem szabályozottak), aminek befolyásolására vonatkozóan szintén nem rendelkezik nagy erôvel a TSO, így ezen a területen is jelentôs kockázattal szembesül a társaság. Emellett a magyar átviteli rendszerirányítónak bevétele származik az ITC-mechanizmusból is, amelyet Európában alkalmaznak a TSO-k egymás közötti kompenzálására a tranzitjellegú, az adott ország villamosenergia-rendszerén áthaladó villamosenergia-szállításokért. Ebben a tekintetben a TSO bevétele szintén tóle független tényezók függvénye.

Azok a piacok, melyeken az átviteli rendszerirányító (sokszor egyetlen) vevóként jelenik meg, általában több eladóval jellemezhetók. Az átviteli rendszerirányítónak a rendszerszintú szolgáltatások nyújtásához, a kiegyenlítés végzéséhez, az átviteli hálózat veszteségének pótlásához villamos energiát kell beszereznie. A villamosenergia-beszerzés forrásának biztosítására tartalékokat is le kell kötni (primer, szekunder, tercier). Hazánkban a TSO a villamos energiát és a tartalékokat tenderen keresztül köteles beszerezni. Ebból a szempontból az egyik legjelentősebb kockázatot az jelenti, hogy ez elóbbiekben felsoroltak beszerzésére milyen költség mellett kerül sor.

A bemutatott iparági és a TSO piacon betöltött szerepéból fakadó sajátosságok ismerete és figyelembevétele elengedhetetlen feltétele annak, hogy az átviteli 
A területenként egységes kockázatkezelési módszertan kialakítása



rendszerirányító társaságra szabott, hatékony vállalati szintú kockázatkezelési rendszert és módszertant lehessen kialakítani.

\section{Területenként egységes kockázatkezelési mód- szertan kialakítása az átviteli rendszerirányító társaság esetében}

A hatékony kockázatkezelés egyik alapfeltétele, hogy vállalati szinten egységes kockázatkezelési módszertant alakítsanak ki, mely a társaságot érintő valamennyi kockázatot lefedi. Az átviteli rendszerirányító társaság területenként egységes kockázatkezelés-módszertani kialakításának fóbb lépéseit a 2. ábrában foglaltuk öszsze.

\section{Egységes kockázati definíció/alapelvek meghatározása}

Az egységes kockázatkezelési módszertan kialakításának kulcsfontosságú feltétele, hogy a kockázatokat vállalati szinten egységes definíció és alapelvek mentén azonosítsák. Ha a különbözô vállalati területeken, szervezeti egységekben nem ugyanazon értelmezés és felfogás szerint történik a kockázatok azonosítása, akkor előfordulhat, hogy a kockázatok helyett problémák, hiányosságok merülnek fel, vagy esetleg megnô magának a kockázatnak a hatása, ami nem jelentheti kiindulópontját egy hatékony kockázatkezelési folyamatnak.

A nemzetközi és hazai szakirodalomban számtalan meghatározás található a kockázat fogalmára. Az átviteli rendszerirányító társaság esetében a következő definíció mentén azonosítható a kockázatok: a kockázat olyan bizonytalan kimenetelü esemény, melynek bekövetkezése lényegi befolyással lehet a szervezet által kitüzött célok elérésére és a vállalat üzleti tevékenységére.

A fenti definícióból következik, hogy a kockázat csak olyan esemény lehet, mely bekövetkezésének konkrét hatása a vállalat által előre nem ismert, annak többféle kimenete is lehet, emellett jelentôs hatást gyakorol a vállalat múködésére. A kockázatok különböző típusaira és csoportosítására végtelen számú lehetôség található a szakirodalomban, gyakorlati szempontból azonban egy egységes kockázatkezelési módszertan kialakításához célszerú a különbözô kockázatokat néhány fóbb csoportba sorolni, és lehetooleg homogén területek mentén azonosítani. Mindebból kiindulva a kockázatokat három fóbb területre lehet meghatározni az átviteli rendszerirányító esetében, melynek értelmében múködési, pénzügyi és stratégiai kockázatok különböztethetőek meg. ${ }^{5}$ 
- múködési kockázatok alatt a társaság belsô múködési folyamataiból, eszközeinek és alkalmazottjainak hibáiból fakadó kockázatok (nem gazdasági jellegúek) értendók,

- pénzügyi kockázatok alatt azok a nem a vállalati múködésból fakadó kockázatok értendók, melyek jelentős hatást gyakorolhatnak a társaság gazdasági helyzetére,

- stratégiai kockázatoknak a társaság hosszú távú, stratégiai céljainak megvalósítását veszélyeztető kockázatok tekintendők, amelyek nem feltétlenül gyakorolnak azonnali hatást a társaság múködésére.

$\mathrm{Az}$ átviteli rendszerirányító társaság kockázatainak azonosítása és elemzése a vállalati szinten egységes definíció alkalmazása mellett egységes alapelvek követése mentén történt, az alábbiaknak megfelelően:

- A kockázat lehet pozitív és negatív is: a kockázat bekövetkezésének hatása nemcsak negatív, hanem pozitív is lehet a vállalat szempontjából, ebben az esetben nem a veszélyeztetettség kockázatát, hanem a lehetôség kockázatát kell számításba venni (például előre nem tervezhető kedvezô üzleti körülmények felmerülése).

- A mérhetó, de nem számszerüsíthetó kockázatok esetén a hagyományos mátrixalapú besorolást alkalmaztuk. A hatás, valószínúségmátrix a kockázatok minôsítésére használt hatás és valószínûség-koordinátarendszer, amelyben a hatás és bekövetkezési valószínúségértékek jellemzően ötfokozatú skálán vannak elhelyezve, így minden kockázat egyértelmúen besorolható a mátrix egy cellájának valamelyikébe.

- Nem mérhetố és nem számszerüsithetố kockázatokat is azonosítottunk a kutatás keretében (ilyen kockázatok jellemzóen például a humán eróforráshoz kapcsolódó kockázatok), azonban ezen kockázatok esetében a számszerúsítés érdekében további kutatás javasolt.

- A mérhetó és számszerúsító kockázatokat pénzben fejeztük ki: a vállalati szintú kockázati kitettség meghatározásához a kockázati tényezók számszerûsítése szükséges. A kockázati kitettség azt jelenti, hogy egy adott vállalat milyen mértékú kockázatokkal szembesül, azaz a bizonytalansággal megjósolható események különbözó kimenetei mekkora eltéréseket okozhatnak a vállalat eredményességében a tervekhez képest vagy mekkora veszteségeket generálhatnak. Ehhez alapvetően szükséges, hogy a hatások pénzben jelenjenek meg.

- A kockázatok eloszlásalapú megközelítése: az általános kockázatkezelési gyakorlatban leginkább elterjedt és a szakirodalom által is gyakran ajánlott módszer a valószínúség-hatás keretrendszer, ami a kockázati tényezók következtében bekövetkezô események valószínúségének és hatásának becslésén alapul, túlzottan leegyszerúsíti a valóságot ahhoz, hogy egy hatékony és megfelelő mélységú kockázatelemzés alapjául szolgáljon. Fontos hiányossága ennek a módszernek, hogy rendkívül kevés (jellemzôen egy) kimenetre fókuszál, és sok esetben a kapott eredmény is nehezen értelmezhetô. Ebból kifolyólag a kockázatok számszerúsítésénél egy szofisztikáltabb módszer alkalmazására került sor, a kockázatok eloszlásalapú megközelítésére, mely megmutatja, hogy a kockázat milyen értékeket, mekkora valószínúséggel vehet fel, tehát nemcsak egy kimenetre fókuszál, hanem az összes lehetséges kimenet valószínúségét megmutatja.

- Viszonyítási alap a legfrissebb elfogadott üzleti terv (a következő 12 hónapra vonatkozóan): a kockázatokat alapvetően a tervtől való eltérésként értelmeztük. Konzisztens és megbízható viszonyítási alapot, bázist az elfogadott üzleti terv nyújt, amely 24 hónapra előre, havi bontásban készül. A kockázatkezelési módszertan kialakítása során a dinamikus szemlélet követése volt a cél. Az üzleti tervadatok gördülő figyelembevétele lehetőséget ad arra, hogy ne csak az adott üzleti évben fennálló kockázati kitettség számszerúsítésére, hanem mindig az adott pillanathoz képesti következő 12 hónapra vonatkozó bizonytalanság számszerúsítésére kerüljön sor. Az egyes kockázatok számszerúsítésekor tehát azt a hatást kell meghatározni, amely megmutatja, hogy az adott kockázat bekövetkezése mekkora eltérést okozhat a következő 12 hónapra vonatkozó üzleti tervben szereplő értékekhez képest.

- Idôtáv: múködési és pénzügyi kockázatok esetében a vizsgálat fókusza - az általános vállalati gyakorlatnak megfelelően - rövid távú (1 év), stratégiai kockázatok esetében hosszabb távú (több év).

- Eredmény- és cash flow-hatás: a kockázatok számszerúsítéséhez meg kell vizsgálni, hogy az azonosított kockázatoknak milyen hatásuk lehet a társaság múködésére. Ebben az esetben a két legfontosabb hatás az adózás elótti eredményre, illetve a pénzállományra gyakorolt hatás. A kockázati kitettség meghatározása során azt kell vizsgálni, hogy a kockázati tényezók bekövetkezése milyen eltérést okoz a tervezett eredmény- és pénzállomány-értékekhez képest. A pénzállomány válto- 
zásának hatásait célszerú egy éves idôtáv mellett havi szinten is megvizsgálni.

Az egységes kockázati definíció és alapelvek meghatározását követően kerülhet sor az átviteli rendszerirányító társaság fóbb kockázatainak azonosítására.

\section{Kockázatok azonosítása}

Egy olyan komplex múködéssel jellemezhetô szervezet, mint az átviteli rendszerirányító társaság esetében a kockázatok azonosításánál a bottom-up megközelítést érdemes alkalmazni, mert a kiterjedt tevékenységi kör miatt az egyes tevékenységekkel foglalkozó szervezeti egységekben (igazgatóságokban) található meg a megfelelő tudás az összes kockázat azonosítására. Ebben a megközelítésben azon igazgatóság munkatársainak kell meghatározni az egyes kockázatokat, melyet az adott kockázat a legnagyobb mértékben érint. A bottom-up megközelítés mellett fontos, hogy legyen az azonosítás során egy top-down szemléletmód is beépítve, amelynek segítségével az összvállalati kockázatokat lehet azonosítani, illetve kiszúrni az esetleges duplikációkat és inkonzisztenciákat.

A kockázatok igazgatóságok szerinti azonosítása során az alábbi releváns módszertanokat lehet alkalmazni:

- Brainstorming, konzultációk: az igazgatóság munkatársai között lefolytatott közös ötletelés, mely hozzájárul az igazgatóságot érintő kockázatok közel teljes körú feltérképezésére.

- Kockázatkezelési workshop: az egyes igazgatóságok által azonosított kockázatok között - a szervezet összetett múködése következtében vélhetôen számos olyan található, mely átfedi egymást. Az átfedések kiküszöbölése érdekében érdemes olyan kockázatkezelési workshopot szervezni, melyben a magasabb szintú vezetốk vesznek részt, akik át tudják tekinteni a társaság múködésének nagyobb területeit is. A kockázatkezelési workshop emellett az egyes igazgatóságokhoz kevésbé köthetô, összvállalati kockázatok azonosítására is alkalmas.

- Esetelemzés: ez az eszköz elsősorban akkor alkalmazandó, ha a múltban történtek olyan események, melyek a társaság eredményére jelentős negatív hatást gyakoroltak. Ezen események részletes elemzése rávilágít arra, hogy melyek lehetnek azok a kockázatok, melyek ilyen események megvalósulásához vezethetnek.

Az átviteli rendszerirányító társaság esetében a kockázatok azonosítása a társaság egyes szervezeti egységei, igazgatóságai mentén valósult meg, az alábbiaknak megfelelóen: ${ }^{6}$
- Átviteli Igazgatóság (ÁIG) területéhez kapcsolódó kockázatok,

- Rendszerirányítási Igazgatóság (RIG) területéhez kapcsolódó kockázatok,

- Piacmúködtetési Igazgatóság (PMIG) területéhez kapcsolódó kockázatok,

- Gazdasági Igazgatóság (GIG) területéhez kapcsolódó kockázatok,

- Informatikai Igazgatóság területéhez kapcsolódó kockázatok,

- Üzemviteli Igazgatóság (ÜZIG) területéhez kapcsolódó kockázatok,

- Vezérigazgatói (VIG) szinten jelentkezô kockázatok (ideértve a közvetlenül a vezérigazgató alá tartozó igazgatóságokhoz kapcsolódó kockázatokat is).

A szervezeti egységek szerinti kockázatazonosítás elsôdlegessége a kutatás során háttérbe szorította a folyamatalapú kockázatazonosítást. Módszertanilag indokolt a folyamatalapú megközelítés jövőbeli vizsgálata is.

Az egyes igazgatóságok esetében azonosított kockázatok többségében múködési kockázatoknak tekinthetóek, kivételt ez alól a GIG Pénzügyi Osztályához tartozó pénzügyi kockázatok jelentenek, valamint azon aggregált stratégiai szintú kockázatok, melyek vezérigazgatói szinten jelentkeznek.

A kockázatok azonosításánál a teljes körüség elvének követése célszerú, melynek értelmében az azonnali eredményhatással nem járó, vagy nehezen számszerúsíthetô kockázatokat is figyelembe kell venni. Fontos kiemelni, hogy a kockázatok azonosításánál mindenképpen magát a kockázatot kell leírni, nem pedig annak hatásait. A kockázatok későbbi értékelésének és számszerúsítésének elősegítése érdekében az egyes kockázati tényezóknél a következmények meghatározása is javasolt. A kockázatok hatékony azonosítása érdekében célszerú egy egységes formát/sémát kidolgozni, mely tartalmazza a kockázat megnevezését, leírását (következményekkel együtt) és a felelős szakterület nevét.

A kockázatok azonosítása során a kidolgozott módszertan újszerüségét elsősorban az adja, hogy kiemelt figyelmet kell szentelni az olyan kockázatokra, melyek az átviteli rendszerirányító társaság villamosenergiapiacon betöltött szerepéból, a társaság alaptevékenységéból erednek, és amelyek semmilyen más vállalatra nem jellemzóek. Az alábbiakban felsorolt kockázatok ilyen TSO-specifikus kockázatoknak tekinthetők:

- Rendszerterhelési becslések pontatlansága: a vállalat nem képes az energiarendszer egészére 
megfelelő pontossággal megbecsülni a forrásoldali tervezés alapjául szolgáló várható fogyasztói igényeket, nem képes megfelelően meghatározni a szükséges forrásoldali összetételt, ami többletköltséget okoz.

- ITC-bevételek ingadozása: a nemzetközi kompenzációs mechanizmusból származó bevételek a TSO-tól független tényezók okán erôteljesen ingadozhatnak. Az ingadozásnak hatása jelenleg a fogyasztói tarifákra van, a vállalat bevételét igen, likviditását átmenetileg, üzleti eredményességét nem, mindössze pénzügyi eredményességét érinti.

- Hálózati veszteség költsége: a hálózati veszteség pótlására menetrend szerint beszerzett villamos energia költsége eltérhet a tervtôl és a tarifában megállapított értéktôl, melynek cash flow- és eredményhatása is van.

- Tarifakockázat: a tarifa meghatározásának módja és értékének alakulása jelentős kockázatot hordoz az átviteli rendszerirányító társaság szempontjából. A jelenleg érvényes módszertan alkalmazása esetén is számos tényezó befolyásolja a tarifa alakulását, de az is kockázatot hordoz magában, ha a tarifa meghatározása során eltekintenek a módszertan előírásaitól. Mindezek következtében a TSO tarifabevételei jelentős mértékben eltérhetnek az üzleti tervben szereplő tervezett bevételtól, aminek jelentős eredményhatása lehet.

\section{Egyedi kockázati hatások számszerüsítése}

Az átviteli rendszerirányító társaság egyes kockázatainak azonosítását követő lépés az egyedi kockázati tényezók hatásainak számszerüsítése, melyhez a kockázatok eloszlásalapú megközelítése jelentette a kiindulási alapot.

A kockázat eloszlása azt mutatja meg, hogy a kockázat milyen értékeket, milyen valószínúséggel vehet fel. Ha ezeket az információkat ismerjük, akkor tudjuk, hogy mekkora lehet a kockázat minimális és maximális, pozitív vagy negatív hatása, és hogy ezek a hatások mekkora valószínúséggel következhetnek be. A kockázatok eloszlása azonban jellemzően nem ismert, ezért a kockázatok eloszlását becsülni kell, vagy a kockázat múltbeli kimeneteleinek ismerete, vagy a jövőre vonatkozó várakozásaink, vagy mindkét tényezô együttes figyelembevétele alapján.

\section{Számszerúsítési módszertanok}



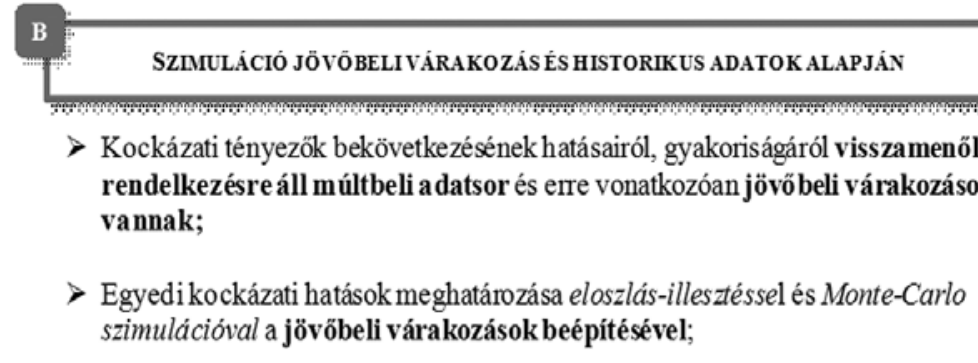

> Szofisztikáltabb módszer a szakértői eloszlás-becslésnél. 


\section{Alkalmazott módszerek}

A kutatás keretében az átviteli rendszerirányító társaság esetében két alapvetô módszer szerint valósult meg az egyedi kockázati hatások számszerúsítése: szakértói eloszlásbecsléssel, valamint szimulációval (jövő́beli várakozás és historikus adatok alapján). Az 1. táblázat összefoglalóan mutatja a két módszer alkalmazásának feltételeit, a szükséges inputokat és az egyes módszerek főbb lépéseit.

A kutatás eredményeképpen azon múködési kockázatok esetében, melyekre vonatkozóan nem álltak rendelkezésre historikus adatok, a hatások számszerúsítése a szakértôi eloszlásbecslés módszerével valósult meg. Azonban azon kockázatoknál, melyekre vonatkozóan historikus adatsorok is rendelkezésre álltak (jellemzôen a pénzügyi és néhány múködési kockázat esetében), pontosabb eredményre vezető egyedi szimulációs modellek kialakítására került sor. ${ }^{7}$

\section{A szimuláció szerepe a modellezésben}

A szimuláció az eloszlások becslésére alkalmas eszköz. A szimuláció során a kockázat különböző kimeneteleit szimuláljuk kellóen sokszor ahhoz, hogy a kockázat eloszlását megközelítsük. Ez azt jelenti, hogy a megadott paraméterek alapján az adott kockázat akár több ezer lehetséges kimenetelét határozzuk meg. Ha a paramétereket jól becsüljük meg, akkor a szimulált értékek jól fogják közelíteni a kockázat tényleges eloszlását, és akkor nem lehetséges, hogy a kockázat a szimuláció maximumánál vagy minimumánál magasabb vagy alacsonyabb értéket vegyen fel. A szakirodalom és a kutatási tapasztalatok alapján általában tízezer lépéses szimuláció futtatása javasolt. Ez a lépésszám már kellően megalapozott eredményeket ad az eloszlás meghatározásához, emellett a szimulációk futtatása jellemzóen nem ütközik sem technikai, sem idôbeli korlátokba.

A kockázatok számszerúsítésének egyik legelterjedtebb gyakorlati támogató eszköze a Monte-Carlo szimuláció, mely nagyszámú véletlen szám generálásán alapuló számítógépes módszer. A modell nagyszámú megismételt mérést szimulál, mely során az inputtényezók értékei a hozzájuk rendelt eloszlások szerint véletlenszerúen generálódnak. A Monte-Carlo szimuláció a kockázatok széles skálájának modellezésére használt eszköz, mely az ismert függvényekkel leírható bizonytalan bemeneti paraméterrel jellemzett esemény lehetséges kimenetelét és azok valószínúségét vizsgálja.

$\mathrm{Az}$ átviteli rendszerirányító társaság területenként egységes kockázatkezelési módszertanának kialakítása során a fentebb vázolt szimulációs eljárás mind az egyedi kockázati tényezók számszerúsítésekor, mind az egyedi kockázatok összegzésekor alkalmazható. Az egyedi kockázatok szimulációjának kettős szerepe van. Egyrészt a szimuláció során becsült eloszlás segítségével különbözô kockázati mérôszámokkal jellemezhetô az adott kockázat. Másrészt a kockázatok összegzése során az összegzố modellben szimulált eloszlások felhasználhatók olyan módon, hogy az összes egyedi kockázat eloszlásából véletlenszerúen kiválasztható egyegy érték, és e kimenetelek eredményre és cash flow-ra gyakorolt hatása vizsgálható.

A szimuláció eredményeinek ismeretében meghatározhatóvá váltak az egyedi kockázatikitettség- és a vállalati szintû́ kockázatikitettség értékek. A szimulált értékek sưrúség- és eloszlásfüggvényeinek vizsgálatával megállapítottuk, hogy a kockázati tényezők bekövetkezése egyedileg és összességében milyen valószínúséggel, mekkora eltérést okoz a tervezett eredmény- és pénzállomány-értékekhez képest (teljes eloszlást tekintve, minimálisan, maximálisan és átlagosan).

A kockázati kitettség mérésére alkalmas lehet a Value-at-Risk (VaR) mutatószám is, mely általánosan elterjedt, a bankszektorban gyakran alkalmazott mutató, és ami adott időintervallum alatt várható legnagyobb veszteséget mér adott konfidenciaszint mellett. A VaR azonban számos olyan tulajdonsággal rendelkezik, melyek megkérdőjelezik univerzális (a pénzügyi szektoron kívüli) alkalmazhatóságát. ${ }^{8}$

A vállalati szintú VaR megállapításához az egyedi kockázati tényezók VaR-értékének összegzése szükséges. Ez egy rendkívül bonyolult matematikai feladat, ami nehézkessé teszi e mutató számítását. Emellett a VaR egyik legfontosabb hátránya, hogy nem mond semmit a konfidenciaszinten felüli veszteségekrôl. Ez azt jelenti, hogy ha egy kockázat bekövetkezése minimális valószínúséggel (95\%-os konfidenciaszinten például 5\% alatti valószínúséggel) ötmilliárd forint veszteséggel vagy egymilliárd veszteséggel jár, az eloszlás egyéb részeinek egyezősége esetén VaRértékük meg fog egyezni. Ez a probléma azt okozza, hogy például az olyan kockázatok esetében, amikor a bekövetkezés esélye nagyon alacsony, és ha nem következik be, akkor 0 a veszteség (például természeti katasztrófa), a VaR értéke 0 lehet annak ellenére, hogy jelentős kockázatról van szó. Ilyen értelemben kizárólag a VaR-értékek figyelembevétele fontos problémát okozhat, hiszen nem ad elegendố információt az elméletileg elképzelhető legnagyobb veszteségról, amire így a vállalat nem tud felkészülni. Az átviteli rendszerirányító társaságnál azonban a kutatás során az is célunk volt, hogy meghatározzuk a maximális veszteségértékeket annak érdekében, hogy a vállalat- 
vezetés tisztában legyen ennek mértékével. Mindezek tükrében a VaR-mutatót nem alkalmaztuk a kockázati kitettség meghatározása során az átviteli rendszerirányító társaság esetében.

\section{Egyedi szimulációs modellek}

Az egyedi kockázatok számszerúsítésére alkalmas excelalapú szimulációs modellek kidolgozására az alábbi három szakterülethez kapcsolódó kockázatok esetén került sor: ${ }^{9}$

\section{$\checkmark$ Piacmúk ödtetési Igazgatóság (PMIG):}

- peremimport-bevételek,

- rendszertartalékok költsége,

- átviteli hálózati veszteség,

- ITC-bevételek,

- határkapacitások értékesítéséból származó bevételek,

- kiegyenlítő energia/szabályozási energia fedezet.

$\checkmark$ Gazdasági Igazgatóság (GIG): villamosenergia-forgalom, tarifa.

$\checkmark$ Gazdasági Igazgatóság, Pénzügyi Osztály (PÜO): árfolyam, BUBOR, EURIBOR, kamatfelár.

A fentiek mellett külön szimulációs modell alkalmazható azon múködési kockázatok esetében, melyek eloszlására vonatkozóan a szakértői eloszlásbecslés módszere lehetséges. Az alábbiakban az egyes területeken kialakított szimulációs modellek általános logikáját ismertetjük.

\section{Pénzügyi kockázatok számszerúsítésére alkalmas szimulációs modellek}

A pénzügyi kockázatok szimulálására alkalmas modellek alaplogikája, hogy a következó 12 hónapra vonatkozó, árfolyammal/kamatlábakkal kapcsolatos előrejelzéseknél a szimuláció éves szinten a jövő́beli várakozásokra épít, míg havi szinten a historikus adatokra. A kockázatok számszerúsítésének szakirodalmi hátterét megvizsgálva és a kutatásban részt vevő szakemberek véleményét figyelembe véve a modellek kidolgozásakor abból az alapkoncepcióból indultunk ki, hogy reális árfolyam-/kamatpályák szimulálásához megfelelô kiindulási alapot jelentenek a múltban ténylegesen megvalósult historikus pályák. Az akár több mint tíz évre visszamenő adatsorok megfelelő (akár több ezres) elemszámú mintát jelentenek. A kutatás során ugyanakkor arra a következtetésre jutottunk az adott szakterület munkatársaival egyetértésben, hogy kizárólag a múltbeli adatokból való kiindulásnál megalapozottabb eredményre vezet, ha a szakemberek által várt, jövóbeli értékeket is figyelembe veszi a szimuláció, mivel az adott terület szakemberei rendelkeznek a legtöbb információval az egyes kockázatok alakulását illetôen. Ezért a múltbeli adatok mellett a várakozások is beépültek a modellekbe.

Ez a gyakorlatban azt jelenti, hogy az adott idôszaki kockázatkezelési jelentés elkészítésekor a következő 12 hónap végére várható árfolyam-/kamatlábértékek, a legfrissebb hiteles banki elórejelzéseket figyelembe véve, az adott szakterület szakvéleménye alapján alakultak ki. Az egyes hónapokra vonatkozó értékeket pedig a múltban ténylegesen megvalósult, reális historikus árfolyam-/kamatpályák szerint szimuláltuk.

A szimuláció elvégzéséhez inputként szükség van az időszaki induló árfolyam-/kamatlábértékre, a 12 hónappal késốbbi várható értékre és a lehetô leghosszabb historikus adatsorra, hogy a valósághoz legközelebb álló jövőbeli értékeket nyerjük. A szimuláció során a következő 12 hónapra vonatkozó kamat-/árfolyamértékek szimulálódnak havi bontásban oly módon, hogy az idôszaki induló érték mindig egy véletlenszerüen választott, a jövő́ben várható értékhez közel esô, múltban megvalósult historikus pálya mentén jut el a jövőben várható szimulált értékhez. Ez a kidolgozott módszer a kockázatok számszerüsítésének újszerú megközelítését jelenti a társaságnál, ugyanis a korábbi vállalati gyakorlat alapján jellemzóen a hatás-valószínúség mátrix segítségével számszerúsítették a kockázatokat. Emellett jóval pontosabb eredményre vezet, mintha kizárólag a szakértôi eloszlásbecslés módszerével számítanák a kockázatokat.

A modell elôször az éves historikus pályákat szimulálja, mely a hónapok közötti ingadozások leképezésére alkalmas. Második lépésként a szimuláció lépésszámától függóen az éves változásra vonatkozó értékek szimulálódnak, melyek várható értéke megegyezik a szakterület által megadott várható éves változás értékével. Ezt követően a modell megszámolja, hogy hány darab historikus pálya felel meg megközelítóleg (meghatározott hibahatáron belül) a szimulált éves értéknek, és a szimuláció során ezek közül véletlenszerúen választanak ki egy historikus pályát, mely megadja a havi változásokat úgy, hogy a végső érték megközelítőleg a szimulált érték legyen.

A pénzügyi kockázatok szimulálására alkalmas modellek futtatásának végső eredménye a havi szimulált kamatláb-/árfolyamérték (a szimulációs lépések számától függően), mely értékeket az üzleti tervben szereplő árfolyam-/kamatlábértékek helyett kell beilleszteni az összegző modellbe. 


\section{Múködési (PMIG) kockázatok számszerúsítésére alkalmas szimulációs modellek}

A PMIG-területhez kapcsolódó múködési kockázatokra kidolgozott szimulációs modellek alaplogikája megegyezik a pénzügyi kockázatoknál alkalmazott logikával. A modell az adott kockázat alakulásával kapcsolatos várakozásokra épít éves szinten, a havi változásokat historikus pályák alapján vezeti le, azonban a szimuláció némiképp eltérô módszertan szerint valósul meg az elóbbiekben bemutatotthoz képest.

Ezeknél a modelleknél nincs szükség az idôszaki induló értékek megadására, helyette a várható, maximális, minimális éves bevétel-/költségértékek meghatározása szükséges. E módszertan mögött az az alapelv húzódik, hogy a PMIG területén jelentkező kockázatok számszerúsítéséhez a legjobb kiindulási alapot az adott területen dolgozók szakvéleménye jelenti. A kutatás során rendelkezésre álló információkat figyelembe véve és az egyes kockázatok múltbeli alakulását megvizsgálva a kutatásban résztvevớk arra az eredményre jutottak, hogy e kockázatok jövốbeli alakulásáról a legpontosabb információval az adott szakterületen dolgozó emberek rendelkeznek (több éves szakmai tapasztalataikból kiindulva), mert e kockázatok esetében gyakran vagy nem azonosítható egzakt módon befolyásoló tényezó, vagy alakulásuk olyan sok tényezố függvénye, melyek közötti kapcsolatok feltérképezése irreálisan sok ráfordítást igényelne. Természetesen azon kockázatoknál, melyek alakulása jól definiálható, exogén tényezőktốl (pl. tôzsdei árak) is függ (pl. átviteli hálózati veszteség költsége), e tényezók beépülnek a modellekbe. A költségek/ bevételek havi alakulásának szimulálására vonatkozóan a kutatás során arra a következtetésre jutottunk, hogy a szakértók által becsült éves értékek havi szintú lebontására a leghatékonyabb módszer a múltban megvalósult, historikus pályák figyelembevétele. A modell historikus adatokkal való feltöltését követôen automatikusan kiszámolja a historikus pályákat, azaz, hogy az adott év tényleges bevétel-/költségtétele hogyan oszlott el az egyes hónapok között (adott hónapra az éves bevétel-/ költségtétel hány százaléka esett). Az adott bevétel-/ költségtétel éves értékei automatikusan számolódnak a vizsgált évekre vonatkozóan a várható éves bevétel és a kalkulált szórás alapján. ${ }^{10} \mathrm{~A}$ szimulált éves értékek havi alakulása pedig úgy kalkulálódik, hogy a historikus éves pályák közül véletlenszerúen választva a szimulált éves bevétel-/költségtömeg feloszlik az egyes hónapok között (amelyik hónapokra rendelkezésre állnak tényadatok, azok összegét levonva az éves értékból a fennmaradó hónapokra osztják fel a szimulált bevételt a historikus arányok alapján).
A szimuláció eredménye az adott bevétel-/költségértékek tervtôl való eltérésének eloszlása és várható cash flow-hatása, valamint a szimulációs lépések számától függóen tizenkét havi adat a szimulált bevétel-/ költségértékekre vonatkozóan, melyeket az üzleti tervben szereplő tervértékek helyett kell beilleszteni az öszszegzó modellbe.

\section{Egyéb múköodési kockázatok számszerúsítésére alkalmas szimulációs modell}

Azon múködési kockázati tényezóknél, melyeknél szakértői becslés módszerének alkalmazásával történt az eloszlásbecslés, a kutatásban résztvevók arra az eredményre jutottak, hogy egy közös szimulációs modell keretében célszerú e kockázatok számszerúsítése. A szimuláció eredménye ebben az esetben a szimulációs lépések számának megfelelő eloszlásérték, valamennyi modellben szerepeltetett egyedi kockázati tényező esetében annak megjelölésével, hogy az adott kockázat felmerülése évente egyszer vagy havonta egyenletes eloszlással várható, és milyen eredménykimutatás-sort érint, mely értékeket az összegző modellben kell megjeleníteni.

\section{Tarifamodell}

A kutatás keretében alakítottuk ki az úgynevezett tarifamodellt, mely alapvetốen az átviteli rendszerirányító társaság tarifabevételeinek ingadozásához kapcsolódó kockázat szimulálására alkalmas komplex modell. A modell a jelenlegi tarifa-módszertani útmutatón alapul $^{11}$, ezért felépítésének logikája eltér az előzőekben bemutatott modellekétól. A szimuláció elsősorban a tarifa nagyságát befolyásoló tényezókkel kapcsolatos várakozásokra épít, és a modell mindamellett, hogy szimulálja a tarifabevételeket, a tarifa hatásának, a villamosenergia-forgalom hatásának, e két tényező együttes hatásának számszerúsítésére, valamint arra is alkalmas, hogy a módszertani útmutatótól való eltérés lehetôségét is figyelembe vegye. Külön tarifamodellre azért volt szükség, mert a kutatás során a társaság szakembereivel egyetértésben arra az eredményre jutottunk, hogy az átviteli rendszerirányító társaság szempontjából egy ilyen kiemelt jelentóséggel bíró kockázat esetében, melyet számos, egyértelmúen meghatározható tényezô befolyásol, a legpontosabb eredményre az vezet, ha a tarifát befolyásoló valamennyi tényezốt egy közös rendszerben kezelő, különálló modellben számszerúsítjük.

A tarifamodell a módszertani útmutatóban szerepló, tarifát befolyásoló tényezók egy részénél a szakértôi eloszlásbecslés módszerére épít, azonban azon tényezők 
esetében, melyekre külön egyedi szimulációs modellek alakultak ki, az egyedi szimuláció eredményei vehetók figyelembe.

Ezek az alábbi kockázatok:

- ITC-bevételek,

- átviteli hálózati veszteség költsége,

- EEX-árak,

- villamosenergia-forgalom,

- határkapacitások értékesítéséból származó bevételek,

- kiegyenlítő energia/szabályozási energia fedezet.

A modell alapvetôen ezen eloszlásokból választja ki a tarifát befolyásoló tényezốk egyes értékeit minden szimulációs lépés során és így minden egyes újrakalkuláláskor a tarifa egy új értéke szimulálódik. A különbözô szimulációk ezt a folyamatosan újrakalkulálódó tarifaértéket, illetve a szimulált villamosenergia-forgalmat veszik alapul a tervezett tarifabevételtôl való eltérés meghatározásához. A szimuláció eredményei a következố naptári évre vonatkozó tarifaértékek, a tarifabevétel-tervtôl való eltérésének eloszlása és várható eredményhatása. Mindebból látható, hogy a tarifamodell kialakításához számos TSO-specifikus egyedi kockázati tényező közötti gazdasági összefüggés tudomá- nyos leképezése volt szükséges. A végsố modell pedig a tényezók hatásainak gazdasági vizsgálatát teszi lehetővé, amely a felsôvezetôii döntések alapját képezheti.

Összességében elmondható, hogy a kidolgozott, területenként egységes módszertan a kockázatok számszerúsítésének újszerü megközelítését jelenti. Egy-egy kockázati tényezô hatásának meghatározásakor nemcsak az általánosan elterjedt szakértői becslés módszere jelenti a kiindulási alapot, hanem az, hogy az egyes kockázatokhoz kapcsolódó, a múltban megvalósult események, hatások alapján egy valóban reális jövốbeli állapotokat vázolnak fel az egyes modellek, figyelembe véve azt is, hogy a jelen pillanatban a szakemberek milyen jövóbeli állapotot tartanak legvalószínúbbnek. E megközelítés hazai villamosenergiaipari alkalmazására korábban nem volt dokumentált példa. Emellett a modellek kialakítása során kiemelt figyelmet kapott, hogy az egyes kockázati tényezók közötti közgazdasági összefüggéseket is azonosítani lehessen. Így született például egy olyan komplex modell, mely képes egy olyan kulcsfontosságú kockázati tényező hatásának elemzésére, mint a hatóságilag szabályozott rendszerhasználati díj változásából fakadó kockázat. Ehhez egyéb kockázati tényezók és az azokat alakító változók azonosítása, illetve a közöttük

\section{Az összegzố modell felépítésének logikája}

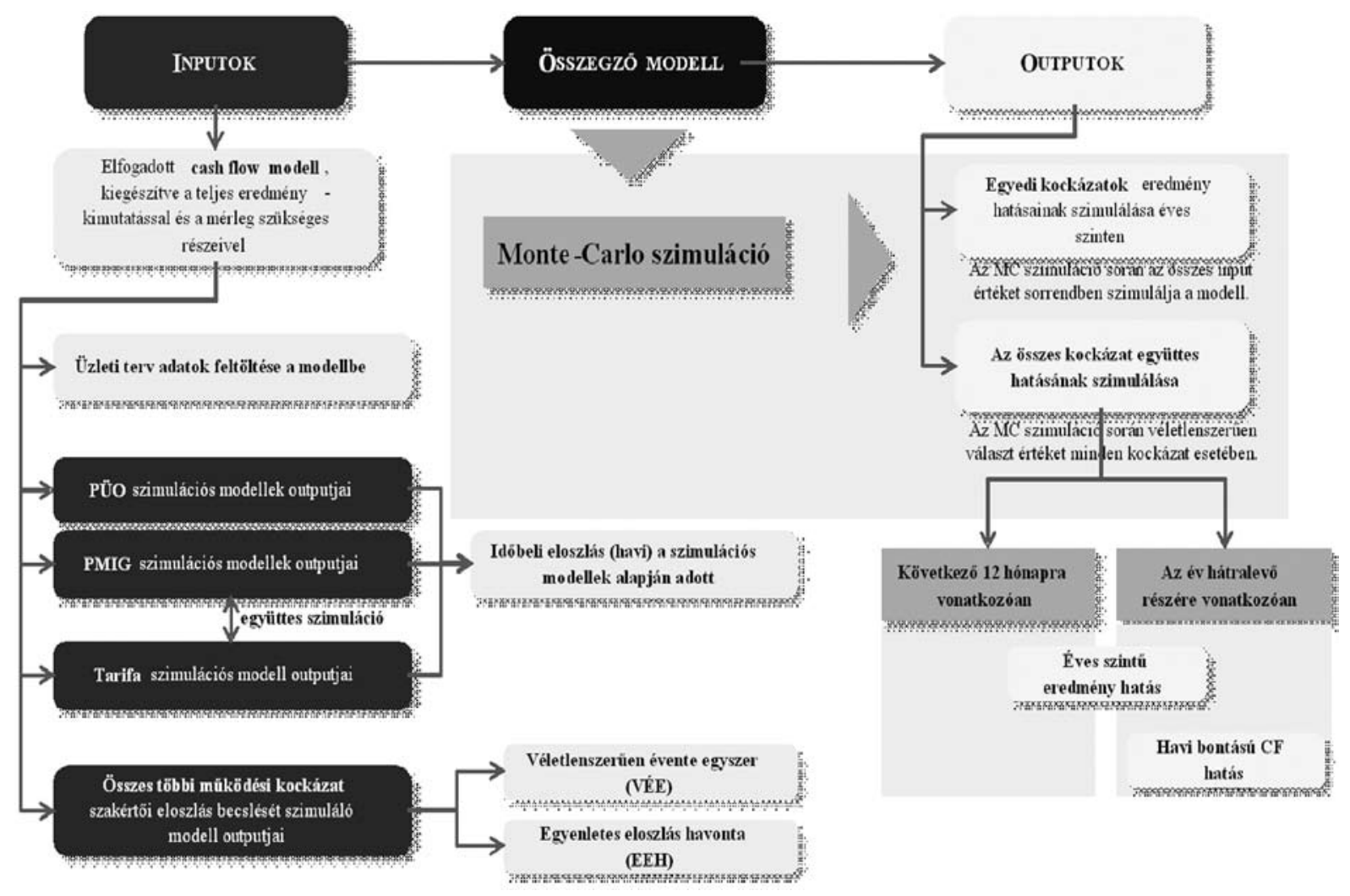


azonosított összefüggések feltárása (pl. átviteli hálózati veszteség, ITC-bevételek stb.), illetve ezek tarifára gyakorolt hatásának azonosítása történt meg a jelenleg hatályos módszertani keretek között. A tarifakockázat ilyen komplex számszerúsítési módszertan szerinti elemzésére és ilyen összetett, az egyes kockázatok közötti összefüggések leképezésére alkalmas modellek kialakítására korábban még nem volt példa.

Az egyedi kockázati tényezốk azonosítását és hatásuk elemzését követően minden kockázati tényező vonatkozásában rendelkezésre állnak az eloszlásra vonatkozó becslések, illetve a szimulációs eredmények. A vállalati szintú kockázati kitettség meghatározásához az egyedi kockázati hatások összegzése szükséges.

\section{Egyedi kockázatok összegzése}

A kockázatok együttes szimulációjának megvalósítására a kutatás eredményeképpen kialakult egy öszszegzó modell, mely alkalmas az egyes területeken azonosított egyedi kockázatok hatásainak vállalati szintú összegzésére az egyedi kockázati tényezók közötti öszszefüggések figyelembevételével.

\section{Az összegző modell felépítése}

Az összegzô modell egy olyan speciális és komplex excelalapú modell, mely alapvetôen a társaság direkt cash flow-modelljére épül (kiegészítve a megfelelő eredménykimutatás- és mérlegsorokkal), és amely minden társaságspecifikus változót és összefüggést figyelembe vesz, és valamennyi azonosított kockázati tényező elemzését lehetôvé teszi.

Az összegző modell kettős célra alkalmazható. Egyrészt azon egyedi kockázatok eredményhatásának szimulációjára, melyekre külön egyedi szimulációs modellek készültek a pénzügyi és múködési területeken. Az egyedi kockázatok szimulációja minden esetben a következő 12 hónapra vonatkozó eredményhatást szimulálja. Ez azt mutatja, hogy ceteris paribus az adott kockázat bekövetkezése esetében várhatóan mekkora lesz az eredeti üzleti tervtôl való eltérés. Az egyedi kockázatok szimulált értékeiból minden egyes értéket egyszer helyettesít be a modell a megfelelő helyre, és így jön ki egy eloszlás az eredménytôl való eltérésre vonatkozóan.

Másrészt az összegzô szimuláció az összes számszerúsített kockázat eredmény- és havi cash flow-hatását is szimulálja. Ebben az esetben minden egyedi kockázat szimulált értékeinek eloszlásából véletlenszerúen kiválaszt egyet, és azt helyettesíti be a modell a megfelelő helyre és hasonlítja össze az így kapott adózás elootti eredményt és cash flow-értéket a tervben szereplő adózás előtti eredményhez, valamint cash flow-értékhez képest. Ennek értelmében minden egyes szimulációs lépés egy lehetséges üzleti környezetet modellez. A modell alkalmas mindezen szimulációk 12 havi előretekintő, valamint az adott év hátralevô részének eredménykockázati szimulációjára bármilyen időpontban.

Az összegzô modell felépítésének logikáját a 3. ábra (előző oldal) szemlélteti.

Az összegző modell innovatív jellegét elsôsorban az jelenti, hogy komplex, szimulációs eljáráson alapuló módszer segítségével dinamikus szemléletben képes az átviteli rendszerirányító társaságot érintő kockázati tényezók egyuittes hatásainak leképezésére, a vállalati szintú kockázati kitettség meghatározására az egyedi kockázati tényezók közötti, korábban még fel nem tárt összefüggések figyelembevételével.

\section{Modellek közötti összefüggések}

Az egyedi szimulációs modellek közötti összefüggéseket, valamint az egyes modellek összegző modellel és a kockázati jelentéssel ${ }^{12}$ való kapcsolatát a 4 . ábra szemlélteti.

A 4. ábra alapján látható, hogy valamennyi kidolgozott egyedi szimulációs modell eredményét keresztuil kell futtatni az összegzó modellen. A pénzügyi kockázatok szimulálására alkalmas modellek futtatásának végsô eredménye a havi szimulált kamatláb-/árfolyam értékek, melyeket egyedi szimulációkon keresztül át kell futtatni az összegző modellen a kapcsolódó pénzügyi eredményhatások szimulálása érdekében. A PMIG területén jelentkezó múködési kockázatok esetében is szükséges a kidolgozott szimulációs modellek outputjainak az összegző modell egyedi kockázati szimulációkon történô keresztülfuttatása, így a cash flow-hatáson keresztüli pénzügyi eredményhatás áttételes meghatározására. A PMIG-kockázatok közül az ÁHV-költség szimulálására szolgáló modell két másik modell eredményeire is épül (EEX árszimulációs modell és villamosenergia-forgalom szimulációs modell, melyek outputjait inputként be kell másolni ebbe a modellbe), illetve a GIG területéhez kapcsolódó múködési kockázatok közül a már említett tarifamodell épül több egyedi szimulációs modellre. A múködési kockázatok közül egyedül a tarifakockázat és villamosenergia-forgalom volatilitásából fakadó kockázat esetén szimulálódik a várható eredményhatás a kidolgozott egyedi szimulációs modellekben. Az átviteli rendszerirányító társaság esetében azonosított kockázatok ilyen komplex rendszerben történô elemzése és egységes módszertan szerinti számszerúsítése mindenképp újszerú.

A szimulációk elvégzését követően mind az egyedi szimulációs modellek, mind az összegzô szimulációs modell végsố eredményét szerepeltetni kell a kockázat- 


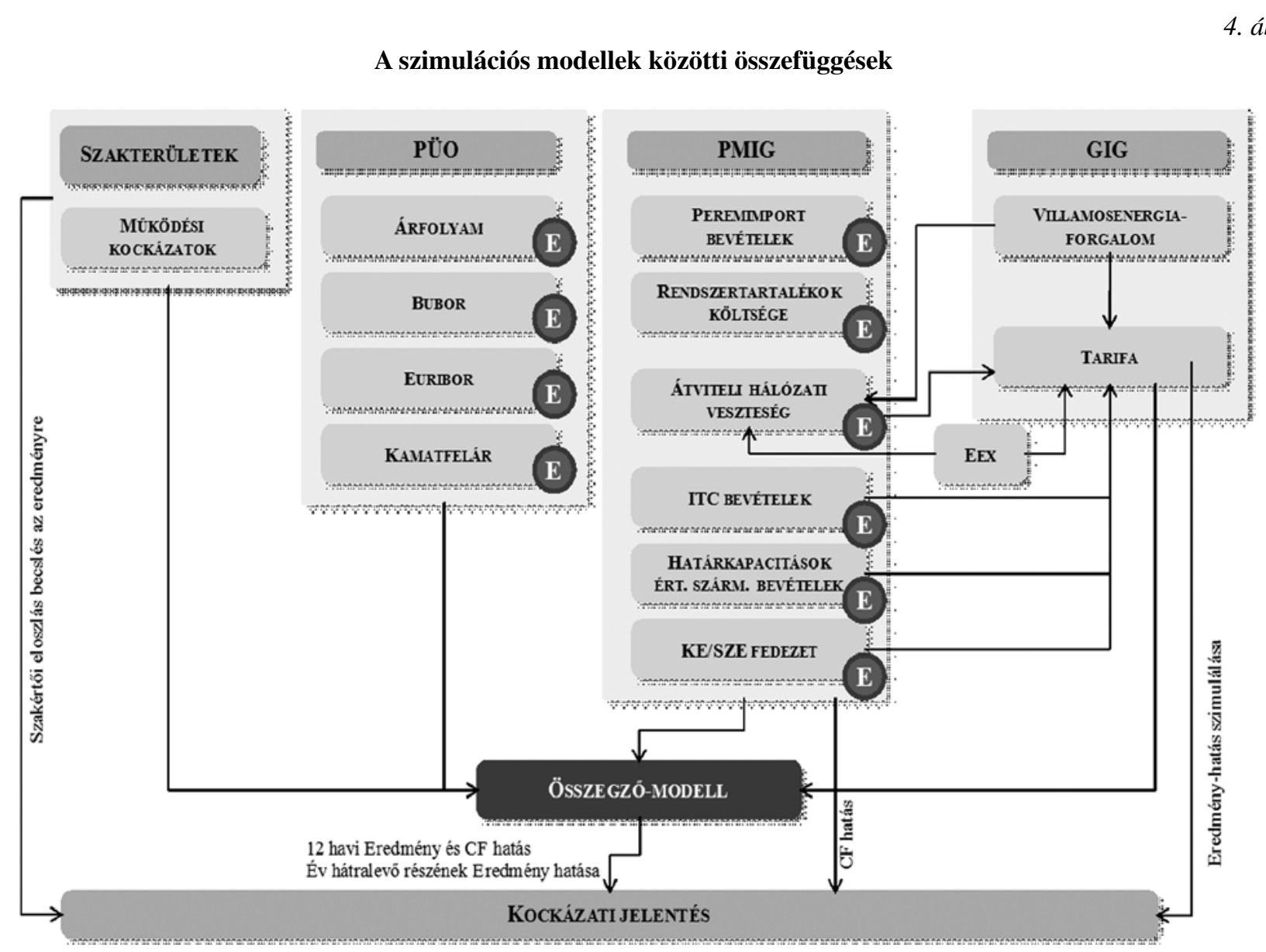

kezelési jelentésben, ezáltal a vállalatvezetés számára ismertté válnak a legjelentősebb kockázati tényezốk és a vállalati szintú kockázati kitettség is.

$\mathrm{Az}$ elóbbiekben bemutatott, a kutatás keretében kidolgozott területenként egységes kockázatazonosítási és -elemzési módszertan alkalmazása megfelelő alapot jelent az átviteli rendszerirányító társaságnak a hatékony vállalati szintú kockázatkezelés megvalósításához. Ennek érdekében elengedhetetlenül szükséges, hogy a kockázatkezelés folyamata a többi vállalati folyamatba integráltan valósuljon meg, valamint hogy a kockázatmenedzsmenthez kapcsolódó tevékenységet végzố valamennyi egyéb vállalati terület egy egységes rendszerben kapcsolódjon össze.

\section{Összegzés}

A vállalati szintú, hatékony kockázatkezelés a vállalatvezetés számára napjaink egyik legnagyobb kihívást jelentő területe, mely az olyan speciális tevékenységet folytató és piaci szerepet betöltő, nemzetgazdasági jelentőséggel bíró vállalat, mint a villamosenergia-ipari átviteli rendszerirányító társaság esetében még nagyobb figyelmet érdemel. A téma aktualitását emellett az is növeli, hogy az elmúlt években egyre nagyobb kihívást jelent az energiaipari TSO-k számára a tevékenységükhöz kapcsolódó és folyamatosan növekvő pénzügyi, illetve cash flow-kockázat hatékony menedzselése, ugyanis e társaságoknak jellemzóen kiemelkedôen nagy mennyiségú pénzáramot kell kezelniük. A cikkben bemutatott, a magyar villamosenergia-ipari átviteli rendszerirányító társasággal együttmúködve kidolgozott új, területenként egységes kockázatkezelési módszertan több szempontból is innovatívnak tekinthetô. Egyedi, speciálisan az átviteli rendszerirányító társaság múködési jellemzóinek megfelelően kialakított kockázatkezelési módszertan, mely újszerü, korábban nem alkalmazott közgazdasági megközelítésben kezeli az iparági és a társaság villamosenergiapiacon betöltött szerepéból fakadó sajátosságokat és a kockázatkezelést a vállalati szervezeti struktúrához a lehetó legjobban közelíti. Emellett egy olyan komplex, matematikailag koherens, szimulációkon alapuló számszerüsítési módszertan, mely alkalmas az egyes területeken azonosított egyedi kockázatok hatásainak vállalati szintü összegzésére az egyedi kockázati tényezók közötti, korábban még fel nem tárt összefüggések figyelembevételével. 


\section{Lábjegyzet}

${ }^{1}$ Hágen (2005) - 3. oldal

${ }^{2}$ Hornai (2001) - 24. oldal alapján saját kidolgozás

${ }^{3}$ Weber (2005)

${ }^{4}$ MAVIR (2011) - 19. old.

${ }^{5}$ Collier (2009) - 62. oldal, Hornai (2001) - 42. oldal, GARP (2009) - 13. oldal alapján saját csoportosítás

${ }^{6}$ MAVIR (2011) - 55. old.

${ }^{7}$ A kutatás keretében azonosítottuk a stratégiai kockázatokat is, azonban az EU Harmadik Energia Csomagjának magyarországi átültetésének következtében jelentôs változások várhatóak az átviteli rendszerirányító múködését tekintve (ITO- modellre való átállás), ezért a stratégiai kockázatok mélyrehatóbb elemzésére és számszerúsítésére nem került sor a kutatás során.

${ }^{8}$ Tan - Chan (2002)

${ }^{9}$ Ennek elsódleges oka, hogy a fentebbi szakterületekhez tartozó kockázatok esetében álltak rendelkezésre megfelelő hosszúságú és minőségú historikus adatsorok és olyan összefüggések, módszertanok, melyek alapján lehetővé vált külön szimulációs modellek kidolgozása.

${ }^{10}$ A szórás a maximális-minimális éves bevétel különbségének hatoda.

${ }^{11}$ A villamos energia rendszerhasználati díjak szabályozásának 2009-2012-es periódusra vonatkozó módszertana elérhető és megtekinthetô a Magyar Energia Hivatal honlapján az alábbi linken: http://www.eh.gov.hu/gcpdocs/201105/skmbt_ c451101122115201.pdf
${ }^{12}$ A társaságnál alkalmazott jelenlegi gyakorlat értelmében évente többször (rendszeres időközönként) kockázatkezelési jelentés készül.

\section{Felhasznált irodalom}

Collier, P. (2009): Fundamentals of Risk Management. Oxford: Elsevier

GARP (2009): Foundations of Energy Risk Management. Chichester: John Wiley \& Sons

Hágen István Zs. (2005): Controllingszemlélet. Prezentáció.

Hornai G. (2001): Kockázat és kockázatkezelés. in: AMagyar Villamos Múvek közleményei, 2001/04. p. 40-46.

Kok-Hui Tan - Inn-Leng Chan (2002): Stress testing using VaR approach. http://www.sciencedirect.com/science/ article/B6VGT-47CY0JR-2/2/ea13d6a0821f48d26203 98ace4bb299f

MAVIR (2011): Éves jelentés - 2010 http://www.mavir.hu/c/ document_library/get_file?uuid=55da97ef-bf75-48838910-271ecf0d2a42\& groupId=10258

Weber, C. (2005): Uncertainty in the Electric Power Industry. London: Springer Science + Business Media

Cikk beérkezett: 2012. 2. hó

Lektori vélemény alapján véglegesítve: 2012. 3. hó

\section{KEDVES OLVASÓ! KÉREM, NE FELEJTSE EL MEGÚJÍTANI 2013-RA SZÓLÓ ELÓFIZETÉSÉT!}

\section{O N T E N T S}

POÓR, József - LÁSZLó, Gyula - BEKE, Jenố - ÓHEGYI, Katalin - KOLBE, Tamás

Evolution of Flexible Remuneration/Cafeteria Systems - Past, Present and Future. 2

\section{BRAUN, Róbert}

Corporate policy - Corporate social responsibility, corporate communities, and future of corporate strategy .18

\section{MIKULÁS, Gábor}

Power distance and institutional collectivism Forecast of competitiveness by text analysis.

\section{KOTSIS, Ágnes}

The effect of overeducation in the case of graduates of University of Debrecen

\section{FIÁTH, Attila - NAGY, Balázs - - TÓTH, Péter - DÓCZI, Szilvia - - DINYA, Mariann}

Development of an integrated risk management methodology for an electricity transmission system operator (TSO) company .

Book Review 